J. Amer. Soc. Hort. Sci. 116(6):974-980. 1991.

\title{
Sulfur Deficiency Influences Vegetative Growth, Chlorophyll and Element Concentrations, and Amino Acids of Pecan
}

\author{
Hening $\mathrm{Hu}^{1}$ and Darrell Sparks ${ }^{2}$ \\ Department of Horticulture, University of Georgia, Athens, GA 30602
}

\author{
John J. Evans ${ }^{3}$ \\ Russell Agricultural Research Center, Agriculture Research Service, U.S. Department of \\ Agriculture, Athens, GA 30613 \\ additional index words. Carya illinoensis, $\mathrm{N}: \mathrm{S}$ ratio, critical values, $\mathrm{N}$ metabolism, nutrition, sulfur
}

\begin{abstract}
Greenhouse-grown pecan [Carya illinoensis (Wangenh.) C. Koch] seedlings were treated with $\mathrm{S}^{2} \mathrm{SO}_{4}^{-2}$ (0 to $4 \mathrm{~mm}$ ) to determine the effect of $S$ on its vegetative growth, chlorophyll concentration, nutrition, and free and protein amino acid content. Sulfur deficiency symptoms occurred when leaf $S$ was $\approx 1.5 \mathrm{mg} \cdot \mathrm{g}^{-1} \mathrm{dry}$ weight or less. Chlorophyll concentration and growth increased curvilinearly with leaf $S$ and had not peaked when leaf $S$ was 2.7 $\mathrm{mg} \cdot \mathrm{g}^{-1}$ dry weight. The $\mathrm{N}: \mathrm{S}$ ratio in the leaf and leaf $\mathrm{S}$ were equally reliable indicators of the $S$ status of the plant, but the optimum ratio was less than the value of 15 found in other plant species. Calcium and Mg decreased with $S$ application, suggesting a direct $\mathrm{SO}_{4}^{-2}$ or $\mathrm{NH}_{4}^{+}$effect. The concentration of all other elements determined was elevated, in one or more plant parts, when $S$ deficiency symptoms were visible. The most conspicuous effect of $S$ deficiency on $\mathbf{N}$ metabolism was a greatly expanded free amino acid pool, mainly arginine. The concentration of free amino acids decreased exponentially with leaf $\mathbf{S}$. Conversely, protein amino acid was inhibited by $\mathbf{S}$ deficiency and increased with leaf $S$ concentration or, perhaps more specifically, with methiouine.
\end{abstract}

In recent years, crop deficiencies of $\mathrm{S}$ have become more frequent and extensive due to increased use of high-analysis fertilizers that contain little or no $\mathrm{S}$, increased crop yields, and decreased use of $S$ as a pesticide. In addition, there has been a decreased gain of atmospheric $S$ by soils and plants as a result of environmental regulations limiting $\mathrm{SO}_{2}$ emission. Furthermore, there has been a decline in $\mathrm{S}$ reserves in surface soils caused by losses in organic matter through erosion and mineralization (Tabatabai, 1980; Tisdale et al., 1985).

Higher plants generally accumulate $\mathrm{S}$ and $\mathrm{N}$ in amounts proportional to that incorporated into protein (Friedrich and Schrader, 1978). Normally, $\approx 75 \%$ to $80 \%$ of the total $\mathrm{N}$ in plants is in protein (Bolton et al., 1976; Stewart and Porter, 1969) and $\approx 90 \%$ of the total $\mathrm{S}$ is in cysteine and methionine, of which nearly all is in protein (Giovanelli, 1987). Because of the close relationship between $\mathrm{S}$ and $\mathrm{N}$, metabolism of $\mathrm{N}$ will be upset by $\mathrm{S}$ deficiency. Such is apparent in pecan, as severely S-deficient pecans accumulate an abnormally high concentration of $\mathrm{N}$ (D.S., unpublished data). The form of $\mathrm{N}$ accumulated in pecan is unknown, but in other plants, accumulation is nonprotein $\mathrm{N}$ in the form of arginine, amide, and nitrate (Bergmann, 1981; DeBoer and Duke, 1982; Dietz, 1989; Klapheck et al., 1982; Rendig et al., 1976). The critical leaf S concentration for pecan growth and fruiting is unknown. A preliminary study (Sparks, 1978) indicated that severe $\mathrm{S}$ deficiency symptoms can be expected when leaf $\mathrm{S}$ is $\approx 1.0 \mathrm{mg} \cdot \mathrm{g}^{-1}$ dry weight or less. The objectives of this study were to determine the relationship between $\mathrm{S}$ and vegetative growth, chlorophyll and element concentrations, and $\mathrm{N}$ metabolism of pecan.

Received for publication 9 Nov. 1990. The cost of publishing this paper was defrayed in part by the payment of page charges. Under postal regulations, this paper therefore must be hereby marked advertisement solely to indicate this fact.

Graduate Student.

${ }^{2}$ Professor.

${ }^{3}$ Plant Physiologist.

\section{Materials and Methods}

Stratified 'Curtis' pecan seeds were planted (one per pot) on 21 Apr. into 1 1-liter plastic pots filled with perlite and placed in the greenhouse, with temperature controls set at $21 \mathrm{C}$ night and 30C day. Hoagland's solution (Hoagland and Arnon, 1950) without $\mathrm{S}$ was applied on 21, 23, and $25 \mathrm{Apr}$. and then weekly until 16 May. At that time, the seedlings, which were $\approx 6$ to 18 $\mathrm{cm}$ tall, were divided into 15 groups with relatively uniformsized seedlings within a group. The seedlings within each group were randomly assigned to either $0,0.2,0.4,0.8,1.2,1.6,2.0$, or $4.0 \mathrm{~mm} \mathrm{~S}$. The design was a randomized complete block.

Sulfur treatment began on 16 May and was applied as $\left(\mathrm{NH}_{4}\right)_{2} \mathrm{~S} \mathrm{O}_{4}$. Whenever $\mathrm{S}$ was applied, $\mathrm{NH}_{4} \mathrm{NO}_{3}$ was used to supply the $\mathrm{S}$-deficient plants the correct equivalence of $\mathrm{N}$, so that every treatment received the same amount of N. Initially, $\mathrm{S}$ was applied weekly for 3 weeks and then every 2 or 3 weeks. The interval between $\mathrm{S}$ applications was increased to induce a wider range of deficiency among the lower $\mathrm{S}$ treatments. Timing of application was based on the progression of deficiency symptoms.

On 4 Aug., 15 weeks after the seed had been planted and 10 days following a treatment, leaf samples from nodes 6 and 7 (numbered from the base of the shoot) were collected for analysis of chlorophyll, free and protein amino acids, total-N, $\mathrm{NO}_{3}-\mathrm{N}$, and $\mathrm{S}$. Leaf samples were pooled into three replications with five plants per experimental unit. Except for those used for chlorophyll analysis, leaf samples were immediately freezedried after collection and ground to pass through a 30-mesh screen. Chlorophyll was extracted and determined in the fresh leaflet according to Arnon (1949).

The seedlings were visually evaluated just before harvest to assess the degree of $\mathrm{S}$ deficiency. Four months after planting, on 21 Aug., the plants were harvested. Plants were pooled into five replications with three plants per experimental unit. Leaves, trunk, and roots were separated, washed in deionized water, dried for $72 \mathrm{~h}$ at $70 \mathrm{C}$, and weighed. These plant parts were 
ground, redried, and analyzed for total $\mathrm{N}$ using a Technicon (Technicon Instruments Corp., Tarrytown, N.Y.)Auto AriaIyzer(Isaac and Johnson, 1976); for $\mathrm{P}, \mathrm{K}, \mathrm{Ca}, \mathrm{Mg}, \mathrm{Fe}, \mathrm{Mn}$, $\mathrm{B}, \mathrm{Cu}$, and $\mathrm{Zn}$, a Jarrell-Ash (Thermo Jarrell-Ash Corp., Franklin, Mass.) plasma-emission spectrometer (Jones, 1977); and for S, a Leco S analyzer (Leco Corpl, St. Joseph, Mich.) (Jones and Isaac, 1972). As methionine and cysteine comprise up to $90 \%$ of the total S in most plants (Giovanelli, 1987) and as our amino acid analysis showed that methionine is the major $\mathrm{S}$ amino acid in pecan, purified commercial methionine was used as the standard for S analysis instead of oil (Jones and Isaac, 1972). Nitrate- $\mathrm{N}$ was determined calorimetrically according to Cataldo et al. (1975).

Free amino acids were extracted from $500 \mathrm{mg}$ of freeze-dried and ground material suspended in $15 \mathrm{ml}$ of distilled $\mathrm{H}_{2} 0$. The suspension was heated in a boiling water bath for $10 \mathrm{~min}$ with intermittent shaking followed by centrifugation at $12,000 \times \mathrm{g}$. After decanting the supernatant, the residue was re-extracted as above two more times, each time using $10 \mathrm{ml} \mathrm{H}_{2} \mathrm{O}$. In the first replication, the residue was extracted only twice. Results from this replication suggested the need for an additional extraction; consequently, the second and third replication were extracted three times. Data from all three replications were used. The supernatants from each extraction were pooled and used as the free amino acid source. The residue after the last extraction was used as the protein amino acid source. Both supernatant and residue were freeze-dried.

Three $\mathrm{ml}$ of $1 \mathrm{NHCI}$ was added to $45 \mathrm{mg}$ of the dried free amino acid residue and boiled in a water bath for $1 \mathrm{~h}$ to hydrolyze asparagine and glutamine to aspartic and glutamic acid, respectively. The amino acid extract was dried under reduced pressure, resuspended in $3 \mathrm{ml}$ of distilled $\mathrm{H}_{\mathrm{z}} \mathrm{O}$, and dried again. The extract was dissolved in $3 \mathrm{ml}$ of sodium citrate buffer $(\mathrm{pH}$ 2.2 ), filtered through $1.4-\mu \mathrm{m}$ filters, and analyzed for amino acids.

Protein amino acids in $120 \mathrm{mg}$ of dry residue were hydrolyzed in $180 \mathrm{ml} 6 \mathrm{~N} \mathrm{HC} 1$ heated at $100 \mathrm{C}$ for $24 \mathrm{~h}$ in a $\mathrm{N}_{2}$ atmosphere. After filtration, the hydrolysate was dried under reduced pressure, resuspended in $100 \mathrm{ml}$ distilled $\mathrm{H}_{2} 0$, and dried again. The dried hydrolysate was dissolved in $15 \mathrm{ml}$ of the sodium citrate buffer, filtered, and the protein amino acids determined in a Beckman model 121 (Beckman Instruments, Fullerton, Calif.) automated amino acid analyzer using the method of Wilkinson et al. (1968).

Data were subjected to regression analysis, (Helwig and Council, 1979; Ezekiel and Fox, 1959). In the cases of nonlinear models, the $\mathrm{r}^{2}$ values were calculated as 1.0 minus the ratio of the residual sum of squares to the corrected total sum of squares (Ware et al., 1982).

\section{Results and Discussion}

Sulfur effects on vegetative growth. In the O-mM S treatment, deficiency symptoms were observed 5 weeks from planting the seed. As a general rule, $\mathrm{S}$ deficiency symptoms (chlorosis and necrosis) appeared on the youngest leaves first. The first symptom of mild $\mathrm{S}$ deficiency was fading of the interveinal areas in the regions between the minute veins. This fading continued until the leaflet was uniformly yellow with only the main veins remaining green. In some cases, but not all, the areas between the minute veins regreened. Also in some, the yellowed areas of the leaf developed a reddish-brown tinge in advanced cases.

Sulfur deficiency symptoms became progressively more severe as a seedling elongated. Newly emerging leaves were golden yellow and failed to turn green. In addition, the tips of the new leaflets tended to curve downward, while, at the same time, the margins of the leaflets tended to curve upwards. With further seedling elongation, emerging leaves were progressively smaller and the internodes became shorter until elongation ceased and the apical meristem died. The veins of the smaller leaves became necrotic, which started as a rusty discontinuous browning but later became continuous. In severe cases, the midrib died from the apical end, followed by death of the leaf blade.

Deficiency symptoms were severe in the O-mM S treatment, and the apical portion of most of the leaflets had died before harvest. With $0.2 \mathrm{mM} \mathrm{S}$, leaflets were golden yellow and cupped, and those with $0.4 \mathrm{mM} \mathrm{S}$ developed mild S deficiency symptoms (pale-yellow to light-green leaflets). With $0.8 \mathrm{mM}$ or more $\mathrm{S}$, the plants appeared normal (Table 1). Plants with $4.0 \mathrm{mM} \mathrm{S}$, double the $\mathrm{S}$ concentration in Hoagland's solution, did not show any toxicity. Very severe $\mathrm{S}$ deficiency symptoms occurred when leaf $\mathrm{S}$ was $\gg 0.5 \mathrm{mg} . \mathrm{g}^{-1}$ or less, severe symptoms when leaf $\mathrm{S}$ was $\gg 1.1 \mathrm{mg} \cdot \mathrm{g}^{-1}$, and mild symptoms when $\mathrm{S}$ was $\gg 1.5 \mathrm{mg} \cdot \mathrm{g}^{-1}$. The leaf $S$ value for severe deficiency is close to that previously reported for severe S deficiency in pecan (Sparks, 1978).

Even though visible deficiency symptoms did not occur when leaf $\mathrm{S}$ was $>1.5 \mathrm{mg} \cdot \mathrm{g}^{-1}$, growth continued to increase at higher

Table 1. Effect of $\mathrm{S}$ on growth characteristics of seedling pecans grown in perlite in the greenhouse. ${ }^{2 . y}$

\begin{tabular}{clrrrr}
\hline \hline \multirow{2}{*}{$\begin{array}{c}\text { Sapplied } \\
(\mathrm{mM})\end{array}$} & & \multicolumn{4}{c}{ Dry wt $(\mathrm{g})$} \\
\cline { 3 - 6 } & S deficiency & Root & Total & Leaf & Trunk \\
\hline 0.0 & Very severe & 3.79 & 6.18 & 1.29 & 1.10 \\
0.2 & Severe & 13.49 & 20.56 & 4.42 & 2.65 \\
0.4 & Mild & 18.07 & 28.33 & 6.95 & 3.31 \\
0.8 & None & 19.74 & 31.10 & 7.71 & 3.65 \\
1.2 & None & 22.13 & 35.81 & 9.54 & 4.14 \\
1.6 & None & 24.83 & 40.01 & 10.43 & 4.75 \\
2.0 & None & 22.29 & 37.69 & 11.02 & 4.38 \\
4.0 & None & 28.39 & 46.63 & 12.85 & 5.39 \\
\hline
\end{tabular}

'After 4 months of growth.

${ }^{y}$ Root dry weight and total dry weight responded curvilinearly to applied S; leaf and trunk dry weights were linear responses. $P<0.05$.

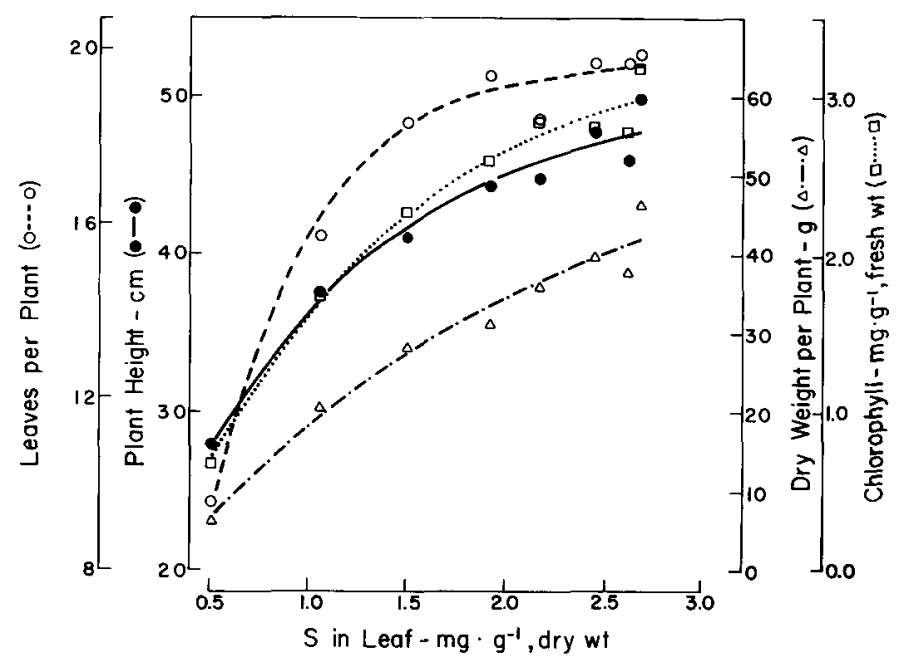

Fig. 1. Leaf chlorophyll and growth of pecan seedlings as a function of leaf S. The relationship of chlorophyll, total dry weight, plant height, and leaf number to leaf $\mathrm{S}$ is described by $\mathrm{Y}=3.4128(1-$ $\left.1.2364 \mathrm{e}^{-0.8623 \times}\right), r^{2}=0.92 ; \mathrm{Y}=59.81\left(1-1.1456 \mathrm{e}^{-0.4998 x}\right), r^{2}$ $=0.86 ; \mathrm{Y}=50.68\left(1-0.7382 \mathrm{e}^{-0.9537 \mathrm{x}}\right), r^{2}=0.78 ; \mathrm{Y}=5+$ $14.76\left(1-1.8493 \mathrm{e}^{-1.897 x}\right), r^{2}=0.85$, respectively. $(P \leq 0.01)$ 


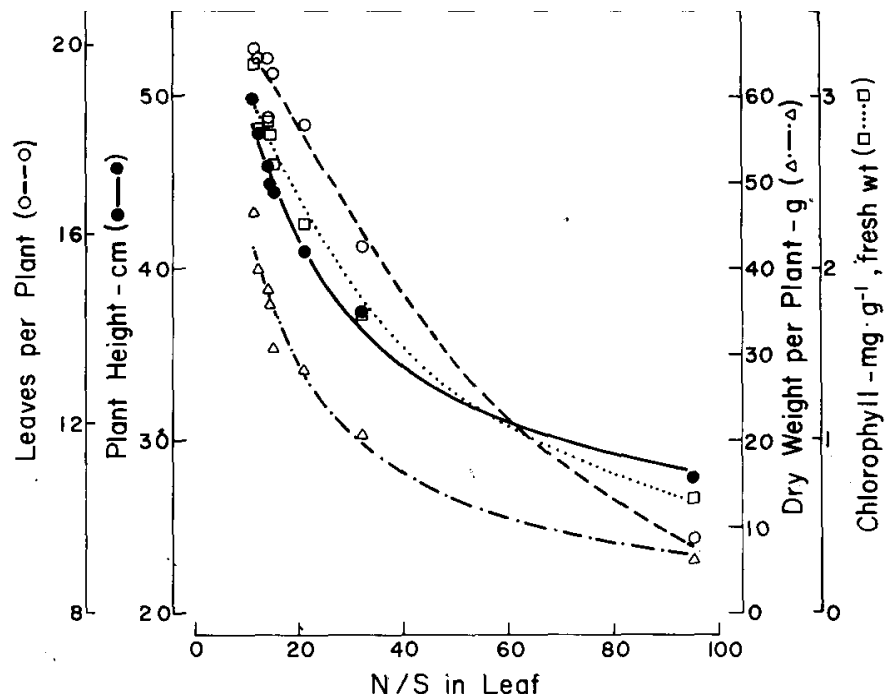

Fig. 2. Leaf chlorophyll and growth of seedling pecans as a function of the $\mathrm{N}: \mathrm{S}$ ratio in the leaf. The relationship of chlorophyll, total dry weight, plant height, and leaf number to the $\mathrm{N}: \mathrm{S}$ ratio is described by: $1 / \mathrm{Y}=3.2014\left(1-1.0783 e^{-29.06 x}\right), r^{2}=0.88 ; 1 / Y$ $=65.53\left(1-1.0125 \mathrm{e}^{-11.68 x}\right), r^{2}=0.86 ; 1 / \mathrm{Y}=55.96(1-$ $\left.0.5879 \mathrm{e}^{-16.59 \mathrm{x}}\right), r^{2}=0.79 ; 1 / \mathrm{Y}=19.9\left(1-0.8683 \mathrm{e}^{-47.78 \mathrm{x}}\right), r^{2}=$ 0.83 , respectively. $(P \leq 0.01)$

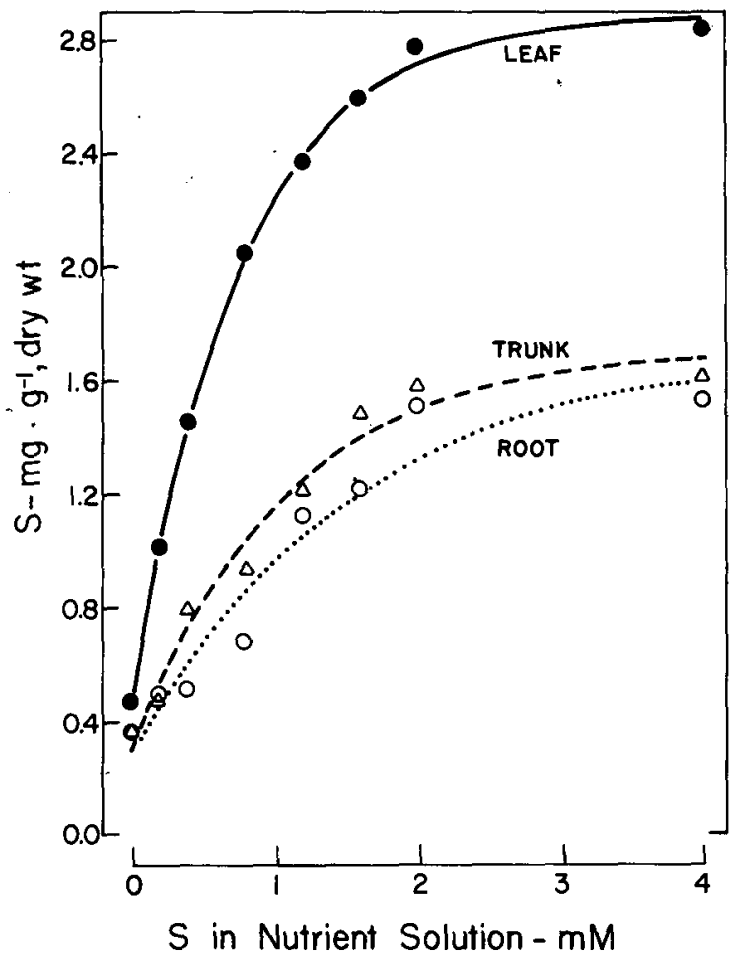

Fig. 3. Sulfur concentration in pecan as a function of $S$ in the nutrient solution. Sulfur in the leaf, trunk, and root is described by $\mathrm{Y}=$ $2.881\left(1-0.8398 \mathrm{e}^{-1.3358 x}\right), r^{2}=0.99 ; \mathrm{Y}=1.715(1-$ $\left.0.8177 \mathrm{e}^{-0.933 t \mathrm{x}}\right), r^{2}=0.92 ; \mathrm{Y}=1.713\left(1-0.8331 \mathrm{e}^{-0.6547 \mathrm{x}}\right), r^{2}$ $=0.85$, respectively. $(P \leq 0.01)$

$S$ levels. Leaf chlorophyll increased curvilinearly with leaf $S$ and had not peaked when leaf $\mathrm{S}$ was $\gg 2.7 \mathrm{mg} \cdot \mathrm{g}^{-1}$ (Fig. 1). Root dry weight increased curvilinearly and leaf and trunk dry weights increased linearly with leaf $S$ (Table 1). The relationship of total dry weight to leaf $S$ was also curvilinear (Fig. 1). Although the number of leaves per plant were near maximum

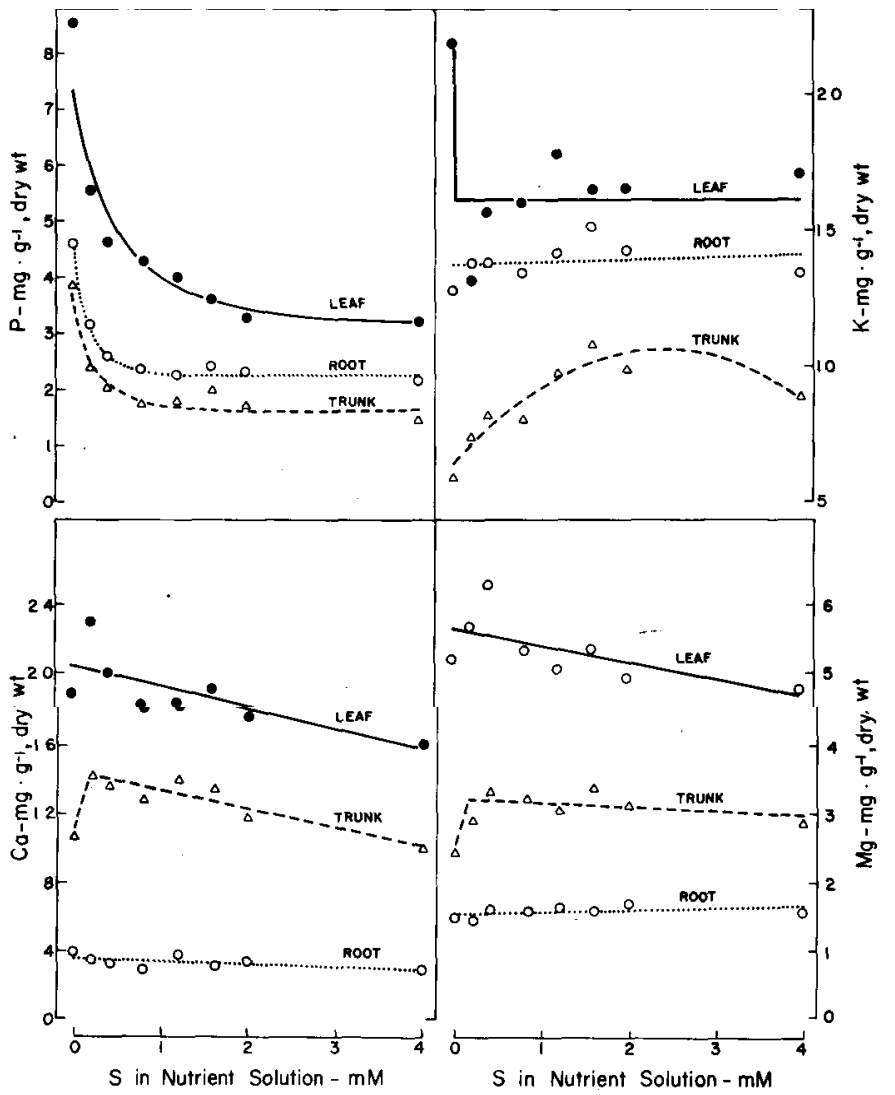

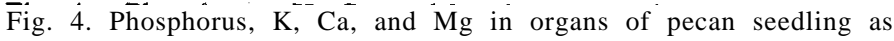
a function of $\mathrm{S}$ in the nutrient solution. Phosphorus in leaf, trunk, and root is described by $1 / \mathrm{Y}=0.3140\left(1-0.5662 \mathrm{e}-1.0127^{\mathrm{x}}\right), \mathrm{P}=$ $0.90 ; 1 / \mathrm{Y}=0.6188\left(1-0.5663 \mathrm{e}^{-2.1316 x}\right), r^{2}=() .59 ; 1 / \mathrm{Y}=$ $0.4467\left(1-0.5161 \mathrm{e}^{3.1401 \times}\right), r^{2}=0.74$, respectively. Potassium in leaf and trunk is described by $\mathrm{Y}=16.091+0.00057771 / \mathrm{X}, \mathrm{r}^{\prime}$ $=0.45$, and $\mathrm{Y}=6.423+3.5 \mathrm{X}-0.7234 \mathrm{X}^{2}, R^{\prime}=0.65$, respectively. Calcium in leaf, trunk, and root is described by $\mathrm{Y}=$ $20.452-0.036 \mathrm{X}, r^{2}=0.42 ; \mathrm{Y}=14.478-1.0814 \mathrm{X}-$ $0.00000038 \mathrm{I} / \mathrm{X}, R^{2}=0.83 ; \mathrm{Y}=3.552-0.0053 \mathrm{X}, r^{2}=0.28$, respectively. Magnesium in leaf and trunk is described by $\mathrm{Y}=$ $5.624-0.2366 \mathrm{X}, \mathrm{r}^{\prime}=0.3227 ; \mathrm{Y}=3.192-0.05367 \mathrm{X}-$ $0.0000000771 / \mathrm{X}, R^{\prime}=0.65$, respectively. $\left(\begin{array}{ll}P & 0.05\end{array}\right)$

when leaf $\mathrm{S}$ was» $2.7 \mathrm{mg} \cdot \mathrm{g}^{-1}$, dry weight accumulation had not peaked. Increased growth was associated with higher leaf dry weight (Table 1) and presumably improved leaf efficiency from the increase in chlorophyll (Fig. 1). As indices of growth continued to increase beyond the range of visible deficiency symptoms, we conclude that there is a relatively wide range of hidden $\mathrm{S}$ deficiency in pecan.

The $\mathrm{N}$ : $\mathrm{S}$ ratio has been proposed to better express the $\mathrm{S}$ status in the plants than total S alone (DeBoer and Duke, 1982; Dijkshoorn and van Wijk, 1967; Stewart and Porter, 1969). The $r^{2}$ values of growth vs. leaf $\mathrm{S}$ (Fig. 1) and growth vs. the $\mathrm{N}$ : $\mathrm{S}$ (Fig. 2) are very similar. Although the $\mathrm{N}: \mathrm{S}$ ratio does not express $\mathrm{S}$ status any better than $\mathrm{S}$ alone in pecan, the ratio can be used as an alternate method of expressing the $S$ status in pecan, as in other plants (DeBoer and Duke, 1982; Dijkshoorn and van Wijk, 1967; Stewart and Porter, 1969). However, the ratio, »10, associated with the highest dry weight accumulation in pecan differs from the ratio of 15 found in lucerne (Medicago sativa L.) (DeBoer and Duke, 1982), wheat (Triticum aesti- . vum), and bean (Phaseohs vulgatis) (Stewart and Porter, 1969). The critical $N$ : $S$ ratio for herbaceous plants seems not directly transferable to pecan. 


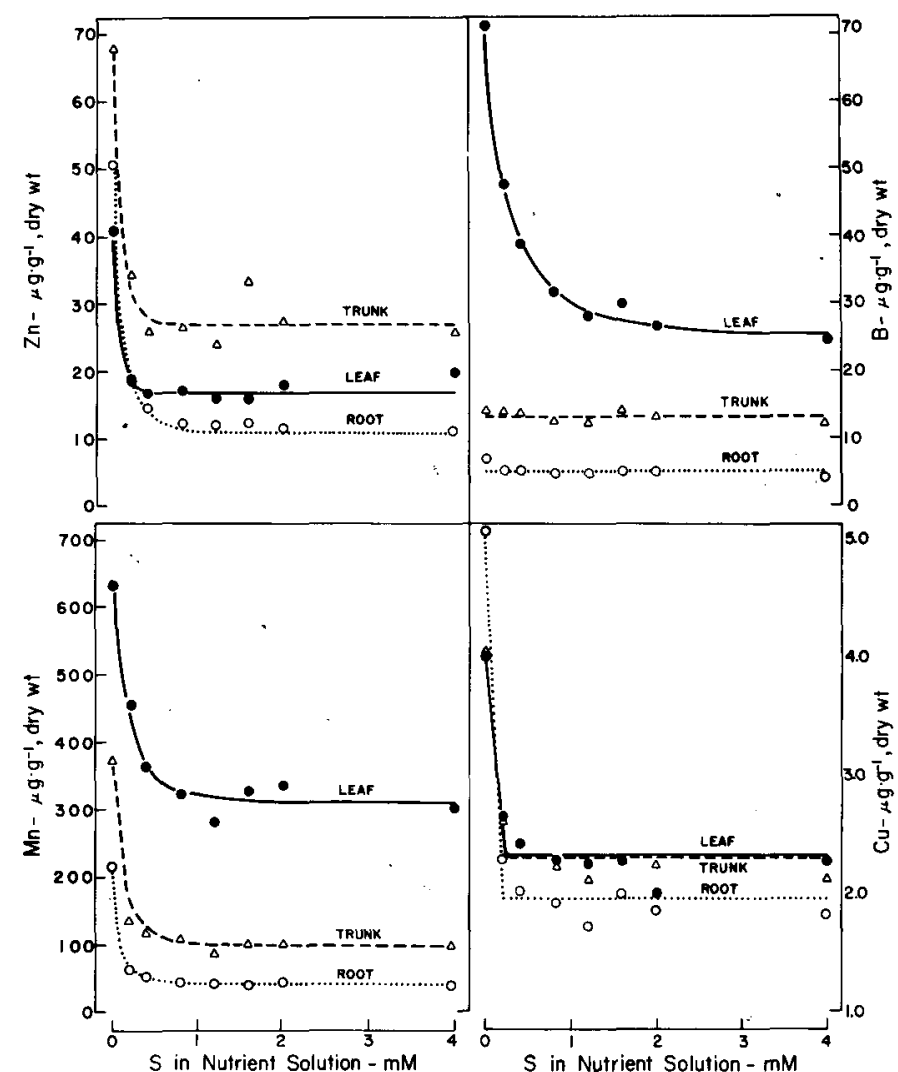

Fig. 5. Zinc, $\mathrm{B}, \mathrm{Mn}$, and $\mathrm{Cu}$ in organs of pecan seedling as a function of $S$ in the nutrient solution. Zinc in leaf, trunk, and root is described by $1 / \mathrm{Y}=0.06024\left(1-0.5785 \mathrm{e}^{-8.1821 \mathrm{x}}\right), r^{2}=0.57 ; 1 / \mathrm{Y}=0.03754$ $\left(1-0.6138 \mathrm{e}^{-6.4971 x}\right), r^{2}=0.71 ; 1 / \mathrm{Y}=0.096\left(1-0.784 \mathrm{e}^{-2.9396 x}\right)$, $r^{2}=0.53$, respectively. Boron in the leaf can be described by $1 / \mathrm{Y}$ $=0.03942\left(1-0.6263 \mathrm{e}^{-1.359 x}\right), r^{2}=0.97$. Manganese in the leaf, trunk, and root is described by $1 / \mathrm{Y}=0.003231\left(1-0.5229 \mathrm{e}^{-3.064 x}\right)$, $r^{2}=0.89 ; 1 / \mathrm{Y}=0.01031\left(1-0.7675 \mathrm{e}^{-2.9548 \mathrm{x}}\right), r^{2}=0.85 ; 1 / \mathrm{Y}$ $=0.02472\left(1-0.8049 \mathrm{e}^{-3.5187 \mathrm{x}}\right), r^{2}=0.97$, respectively. Copper in the leaf, trunk, and root is described by $\mathrm{Y}=2.3131+0.0001691$ $1 / \mathrm{X}, r^{2}=0.26, \mathrm{Y}=2.2998+0.00017471 / \mathrm{X}, r^{2}=0.32, \mathrm{Y}=$ $1.9504+0.00031291 / \mathrm{X}, r^{2}=0.67$, respectively. $(P \leq 0.05)$

Sulfur effects on concentration elements. Nitrogen, $\mathrm{P}$, and $\mathrm{K}$ concentrations were highest in the leaf, intermediate in the root, and lowest in the trunk, with the corresponding order for $\mathrm{Ca}$, $\mathrm{Mg}, \mathrm{S}, \mathrm{Mn}, \mathrm{Cu}$, and $\mathrm{B}$ being leaf, trunk, and root and for $\mathrm{Zn}$, trunk, leaf, and root (Figs. 3-6). The same order for the elements among the three organs was found in a $\mathrm{P}$ study with pecan (Sparks, 1988).

According to Mitscherlich's plant growth equation, increasing the amount of $\mathrm{S}$ applied increased the level of $\mathrm{S}$ in leaves, trunk, and roots (Fig. 3) but approached composition maximums before maximum dry-weight accumulation (Fig. 1 vs. 3). Sulfur application affected the concentration of all other elements in one or more plant parts (Figs. 3-6). Elements not affected in all plant parts were $\mathrm{Fe}$ in the leaf (Fig. 6), B and $\mathrm{Fe}$ in the trunk (Figs. 5 and 6), and $\mathrm{Mg}$ and Bin the root (Figs. 4 and 5). With the exception of $\mathrm{S}$ (Fig, 3) and $\mathrm{K}$ in the trunk (Fig. 4), S application decreased the concentration of elements (Figs. 4-6) or, alternatively, the element concentrations increased with decreasing $S$ in the nutrient solution.

The decrease in element concentration with applied $S$ followed one of four basic equations: $Y=a+b X ; Y=a+b$ $1 / X ; Y=a+b X+c I / X$, or $1 / Y=a(1-b e-")$, which is the inverse of Mitscherlich's growth curve. The linear equa-

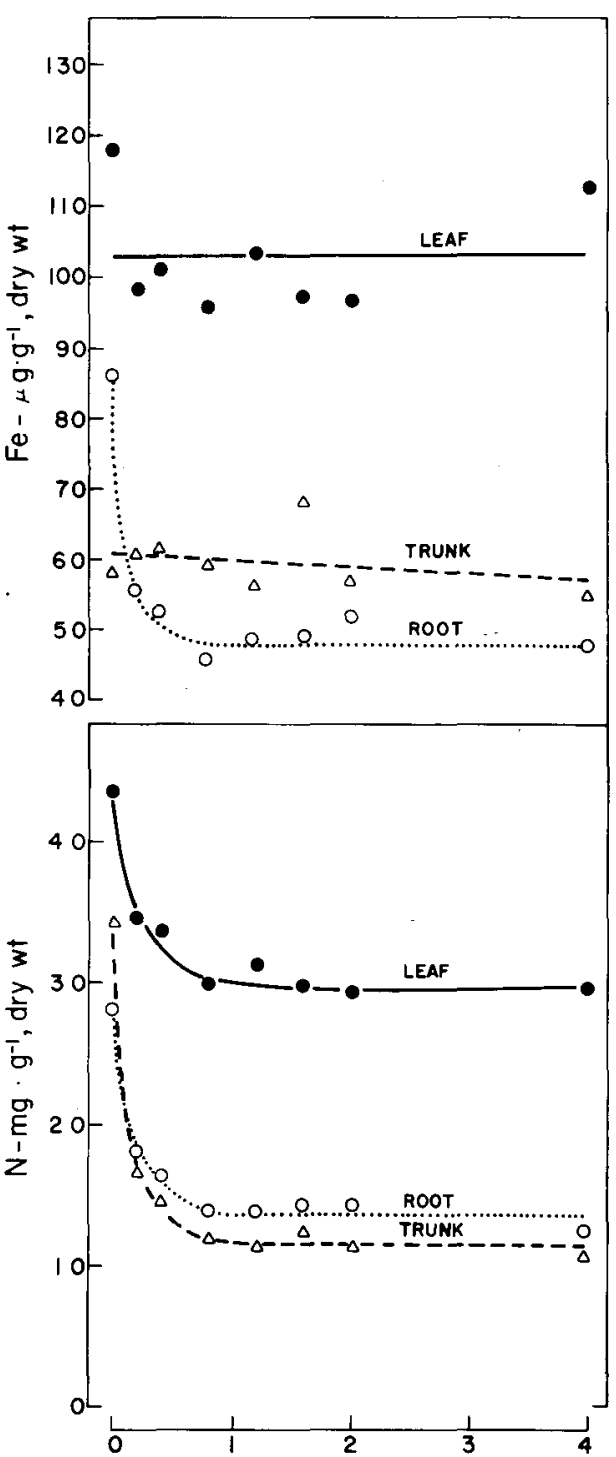

Fig. 6. Iron and total $\mathrm{N}$ in organs of pecan seedling as a function $\mathrm{o}$ $S$ in the nutrient solution. Iron in root is described by $1 / Y=0.02098$ $\left(1-0.4369 e^{-5.6404 x}\right), r^{2}=0.57$. Nitrogen in leaf, trunk, and roo is described by $1 / Y=0.0336\left(1-0.3113 e^{-3.4203 x}\right), r^{2}=0.79$ $1 / \mathrm{Y}=0.0885\left(1-0.6633 \mathrm{e}^{-3.16 \mathrm{x}}\right), r^{2}=0.92 ; 1 / \mathrm{Y}=0.07412(1$ $\left.-0.5129 \mathrm{e}^{-3.1708 \mathrm{x}}\right), r^{2}=0.89$, respectively. $(P \leq 0.05)$

tions and $\mathrm{Y}=\mathrm{a}+\mathrm{bX}+\mathrm{c} 1 \mathrm{X}$ may, indicate competitive absorption and, on this basis, suggest a direct $\mathrm{SO}_{4}^{-2}$ or $\mathrm{NH}_{4}^{+}$ effect or both on $\mathrm{Ca}$ and $\mathrm{Mg}$ (Fig. 4). The equation $\mathrm{Y}=\mathrm{a}+$ b 1/X suggests element imbalances associated with severe $\mathrm{S}$ deficiency; such imbalances occurred only with $\mathrm{K}$ in the leaf (Fig. 4) and $\mathrm{Cu}$ in all plant parts (Fig. 5). The decrease in all other elements, except $\mathrm{K}$ in the trunk (Fig. 4), followed the inverse of Mitscherlich's plant growth equation (Figs. 4-6). Most of the decrease in element concentration occurred between $\mathrm{O}$ and $0.8 \mathrm{mM} \mathrm{S}$ (Figs. 4-6), which corresponds to the range of visible $\mathrm{S}$ deficiency symptoms (Table 1). This correlation between $S$ deficiency and changes in element concentrations suggests element imbalances induced by $\mathrm{S}$ deficiency or growthlimiting levels of $\mathrm{S}$ as such. We attribute the decrease in the element concentrations to dilution from increasing dry matter with increased $\mathrm{S}$. This hypothesis is supported by the inverse relationship of element concentration to dry-weight accumula- 
Table 2. Effect of applied $S$ on free amino acids in the pecan leaf ( $\mu$ moles amino acid/gram dry leaf). ${ }^{z, y}$

\begin{tabular}{lcccccccc}
\hline \multirow{2}{*}{$\begin{array}{l}\text { Amino } \\
\text { acid }\end{array}$} & \multicolumn{7}{c}{ Sulfur in nutrient solution $(\mathrm{mM})$} \\
\cline { 2 - 9 } Lysine & $\mathbf{0}$ & 0.2 & 0.4 & 0.8 & 1.2 & 1.6 & 2.0 & 4.0 \\
Histidine & 12.8 & 6.66 & 3.51 & 1.58 & 1.03 & 0.79 & 0.75 & 0.66 \\
Arginine & 547 & 1.14 & 0.54 & $\mathbf{0 . 1 9}$ & 0.24 & 0.17 & 0.14 & 0.12 \\
Cystine/2 & 0.90 & 0.77 & 0.52 & 0.65 & 0.83 & 0.62 & 0.42 & 0.17 \\
ASX & 8.41 & 6.57 & 5.83 & 4.58 & 4.47 & 4.25 & 4.24 & 3.88 \\
Threonine & 1.29 & 0.95 & 0.67 & 0.63 & 0.50 & 0.52 & 0.55 & 0.46 \\
Serine & 3.84 & 3.24 & 2.20 & 1.47 & 1.23 & 1.14 & 1.12 & 0.95 \\
GLX & 7.51 & 8.34 & 6.91 & 4.81 & 4.39 & 4.34 & 4.71 & 4.19 \\
Proline & $\mathrm{T}$ & $\mathrm{T}$ & $\mathrm{T}$ & $\mathrm{T}$ & $\mathrm{T}$ & $\mathrm{T}$ & $\mathrm{T}$ & $\mathrm{T}$ \\
Glycine & 0.85 & 1.00 & 1.04 & 1.38 & 1.28 & 1.15 & 1.12 & 1.02 \\
Alanine & 2.46 & 2.12 & 1.67 & 1.50 & 1.52 & 1.41 & 1.40 & 1.44 \\
Valine & $\mathrm{T}$ & $\mathrm{T}$ & $\mathrm{T}$ & $\mathrm{T}$ & $\mathrm{T}$ & $\mathrm{T}$ & $\mathrm{T}$ & $\mathrm{T}$ \\
Methionine & $\mathrm{T}$ & $\mathrm{T}$ & $\mathrm{T}$ & $\mathrm{T}$ & $\mathrm{T}$ & $\mathrm{T}$ & $\mathrm{T}$ & $\mathrm{T}$ \\
Isoleucine & $\mathrm{T}$ & $\mathrm{T}$ & $\mathrm{T}$ & $\mathrm{T}$ & $\mathrm{T}$ & $\mathrm{T}$ & $\mathrm{T}$ & $\mathrm{T}$ \\
Leucine & $\mathrm{T}$ & $\mathrm{T}$ & $\mathrm{T}$ & $\mathrm{T}$ & $\mathrm{T}$ & $\mathrm{T}$ & $\mathrm{T}$ & $\mathrm{T}$ \\
Tyrosine & $\mathrm{T}$ & $\mathrm{T}$ & $\mathrm{T}$ & $\mathrm{T}$ & $\mathrm{T}$ & $\mathrm{T}$ & $\mathrm{T}$ & $\mathrm{T}$ \\
Phenylalanine & $\mathrm{T}$ & $\mathrm{T}$ & $\mathrm{T}$ & $\mathrm{T}$ & $\mathrm{T}$ & $\mathrm{T}$ & $\mathrm{T}$ & $\mathrm{T}$ \\
Total & 586.2 & 232.3 & 116.4 & 43.9 & 33.4 & 25.5 & 24.8 & 19.4 \\
\hline
\end{tabular}

${ }^{z}$ The effect of applied S on alanine, threonine, ASX (asparagine and aspartic acid), serine, and GLX (glutamine and glutamic acid) followed the general equation, $1 / Y=a\left(1-b e^{-c x}\right)$; arginine, lysine, and histidine followed $\mathrm{Y}=\mathrm{ae}^{-\mathrm{cx}}$; and glycine followed $\mathrm{Y}=\mathrm{a}+\mathrm{bX}+\mathrm{cX} \mathrm{X}^{2}$. All relationships are statistically significant, $P \leq 0.05$.

$\mathrm{y} \mathrm{T}=$ trace amount.

tion. These results indicate that, except for $\mathrm{Ca}$ and $\mathrm{Mg}$, the effect of applied $S$ in perlite on other elements is an indirect effect associated with $\mathrm{S}$ deficiency. The increase in $\mathrm{N}, \mathrm{P}$, and $B$ concentration with $\mathrm{S}$ deficiency has also been reported for herbaceous plants (Adams and Sheard, 1966; DeBoer and Duke, 1982; Dietz, 1989; Klapheck et al., 1982; Smith et al., 1985; Stewart and Porter, 1969).

Sulfur efects on free and protein amino acids. Except for cystine/2 and glycine, all measurable free amino acids accumulated in severely S-deficient pecans (O mM S treatment) (Table 2). Arginine was the predominant form of the accumulated free amino acids, regardless of treatment, and with $\mathrm{O} \mathrm{mM} \mathrm{S}$, arginine accounted for $\gg 93 \%$ of the total free amino acids. As $\mathrm{S}$ in the nutrient solution increased, free arginine dramatically decreased. Similarly, other measurable free amino acids, with the exception of glycine, decreased with $\mathrm{S}$ application. Glycine increased slightly as applied $\mathrm{S}$ increased from $\mathrm{O}$ to $0.8 \mathrm{mM}$ and decreased at higher levels of S. The S-containing half cystine, which occurred in small amounts, did not correlate well with $S$ application, nor did the other S-containing amino acid, methionine. Like methionine, proline, valine, isoleucine, Ieucine, tyrosine, and phenylalanine all occurred in trace amounts regardless of $\mathrm{S}$ treatment. Total free amino acids in the leaf decreased exponentially with applied S.

Total protein amino acids in the leaf increased with applied $S$ (Table 3), indicating that $S$ deficiency greatly inhibits protein accumulation. Except for half cystine and arginine, all protein amino acids increased with $\mathrm{S}$ application. Cystine/2 occurred only in low or trace amounts. The lack of an increase in protein arginine may have been due to incomplete extraction of free arginine, especially in the low $\mathrm{S}$ treatments. The protein amino acids in severely S-deficient plants correlated closely with those in normal plants (Fig. 7), indicating that the amount of protein, but not the composition, is altered by $\mathrm{S}$ deficiency.

Protein amino acid concentrations increased and those of free amino acids decreased with leaf $\mathrm{S}$ and dry weight (Fig. 8). The relationship of protein amino acids and free amino acids to dry weight paralleled the relationship to leaf $\mathrm{S}$. The parallelism is due to the close relationship between growth and leaf $\mathrm{S}$ (Fig. 1). When free amino acids were near minimum, proteins were approaching a maximum (Fig. 8). These data indicate the interrelationships of amino acids, protein, S deficiency, and growth. Because free arginine was the main component of the free amino acid pool (Table 2), the relationship of free arginine to $S$ or to

Table 3. Effect of applied $S$ on protein amino acids in the pecan leaf ( $\mu$ moles amino acid/gram dry leaf). ${ }^{z, y}$

\begin{tabular}{lcccccccc}
\hline \hline \multirow{2}{*}{$\begin{array}{l}\text { Amino } \\
\text { acid }\end{array}$} & \multicolumn{10}{c}{ Sulfur in nutrient solution (mM) } \\
\cline { 2 - 9 } & 0 & 0.2 & 0.4 & 0.8 & 1.2 & 1.6 & 2.0 & 4.0 \\
\hline Lysine & 32.9 & 53.7 & 64.3 & 72.8 & 78.8 & 78.2 & 81.4 & 82.6 \\
Histidine & 9.1 & 17.7 & 21.9 & 25.0 & 27.2 & 26.6 & 28.2 & 29.4 \\
Arginine & 75.9 & 59.5 & 57.2 & 57.6 & 64.9 & 61.0 & 63.6 & 63.4 \\
Cystine/2 & $\mathrm{T}$ & $\mathrm{T}$ & 0.89 & 1.52 & 1.31 & 1.25 & 1.34 & $\mathrm{~T}$ \\
ASX & 44.1 & 78.6 & 96.8 & 109 & 123 & 119 & 123 & 123 \\
Threonine & 23.8 & 43.2 & 51.2 & 61.3 & 68.7 & 68.1 & 70.3 & 69.6 \\
Serine & 33.6 & 50.5 & 60.7 & 69.2 & 76.8 & 76.0 & 78.4 & 78.9 \\
GLX & 45.3 & 83.4 & 101 & 114 & 128 & 126 & 133 & 138 \\
Proline & 29.3 & 50.6 & 60.8 & 67.9 & 75.4 & 74.5 & 78.1 & 77.8 \\
Glycine & 44.0 & 81.5 & 101 & 115 & 127 & 126 & 129 & 129 \\
Alanine & 39.7 & 73.6 & 91.4 & 104 & 115 & 118 & 124 & 117 \\
Valine & 32.6 & 56.8 & 69.0 & 78.9 & 87.2 & 84.4 & 88.6 & 88.8 \\
Methionine & 7.2 & 15.4 & 16.7 & 20.3 & 22.7 & 21.5 & 23.7 & 21.8 \\
Isoleucine & 23.2 & 42.8 & 51.9 & 59.1 & 64.8 & 63.0 & 66.0 & 65.4 \\
Leucine & 44.5 & 81.3 & 101 & 114 & 125 & 122 & 127 & 126 \\
Tyrosine & 11.6 & 24.7 & 31.6 & 37.0 & 41.0 & 45.5 & 42.0 & 41.3 \\
Phenylalanine & 21.1 & 40.6 & 50.2 & 58.4 & 63.7 & 63.8 & 64.8 & 64.3 \\
Total & 518 & 854 & 1027 & 1165 & 1289 & 1272 & 1322 & 1312 \\
\hline
\end{tabular}

zThe effect of applied $S$ on all protein amino acids followed the general equation, $Y=a(1-$ $b e^{-c x}$ ). The relationship was statistically significant, except in the case of arginine and half cystine, $P \leq 0.01$.

$\mathrm{y} \mathrm{T}=$ trace amount. 


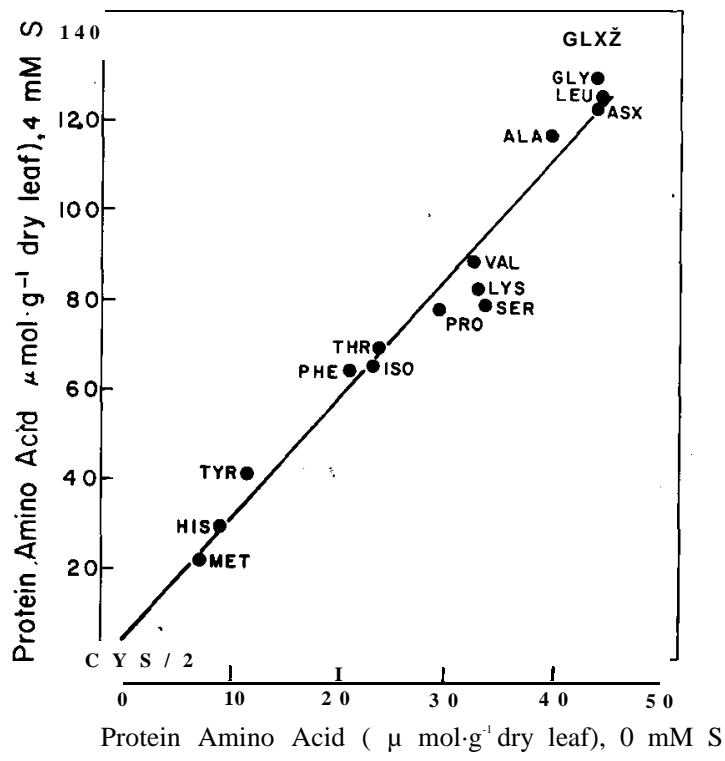

Fig. 7. Relationship of protein amino acids in normal (4 $\mathrm{mM} \mathrm{S}$ in the nutrient solution) vs. S-deficient (0 $\mathrm{mM} \mathrm{S}$ in the nutrient solution) pecan seedlings. The relationship is described by $\mathrm{Y}=3.889+$ $2.688 \mathrm{X}, r^{2}=0.94(P \leq 0.01)$. Arginine is not included in relationship, see text.

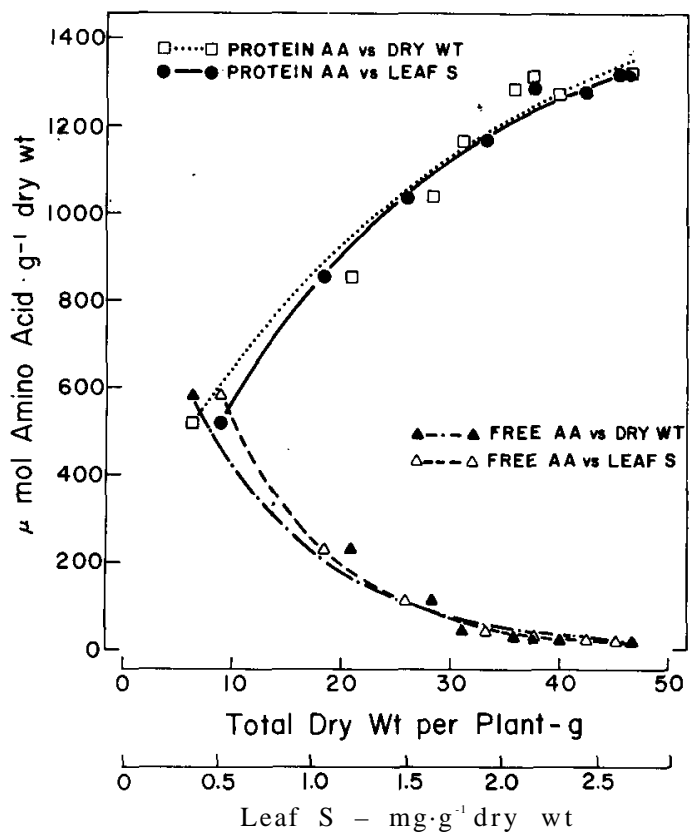

Fig. 8. Relationship of protein amino acids and total free amino acids to total dry weight and leaf $\mathrm{S}$. The relationship between total free amino acids and total dry weight, total free amino acids and leaf $\mathrm{S}$ are described by $\mathrm{Y}=975.5 \mathrm{e}^{0.08332 \mathrm{x}}, \mathrm{r}^{2}=0.95 ; \mathrm{Y}=1420 \mathrm{e}^{-1.7134 \mathrm{x}}$, $r^{2}=0.97$, respectively the relationship between protein amino acids and total dry weight, protein amino acids and leaf $\mathrm{S}$ are de-

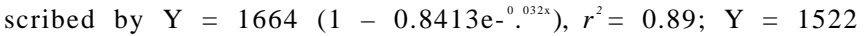
$\left(1-0.9707 \mathrm{e}^{-07547},\right), r^{2}=0.96$, respectively. $(\mathrm{P} \leq 0.01)$

dry weight was similar to the responses of total free amino acids (Fig. 8) and for this reason is not presented.

The relationship between $\mathrm{S}$ application and $\mathrm{N}$ partitioning is summarized in Fig. 9. Plants in the O-mM treatment accumulated the highest concentration of total $\mathrm{N}$. As $\mathrm{S}$ in the nutrient solution was increased, total $\mathrm{N}$ in the leaf rapidly decreased and leveled off when $\mathrm{S}$ was applied between 0.8 to $4.0 \mathrm{mM}$ At $\mathrm{O} \mathrm{mM} \mathrm{S}$,
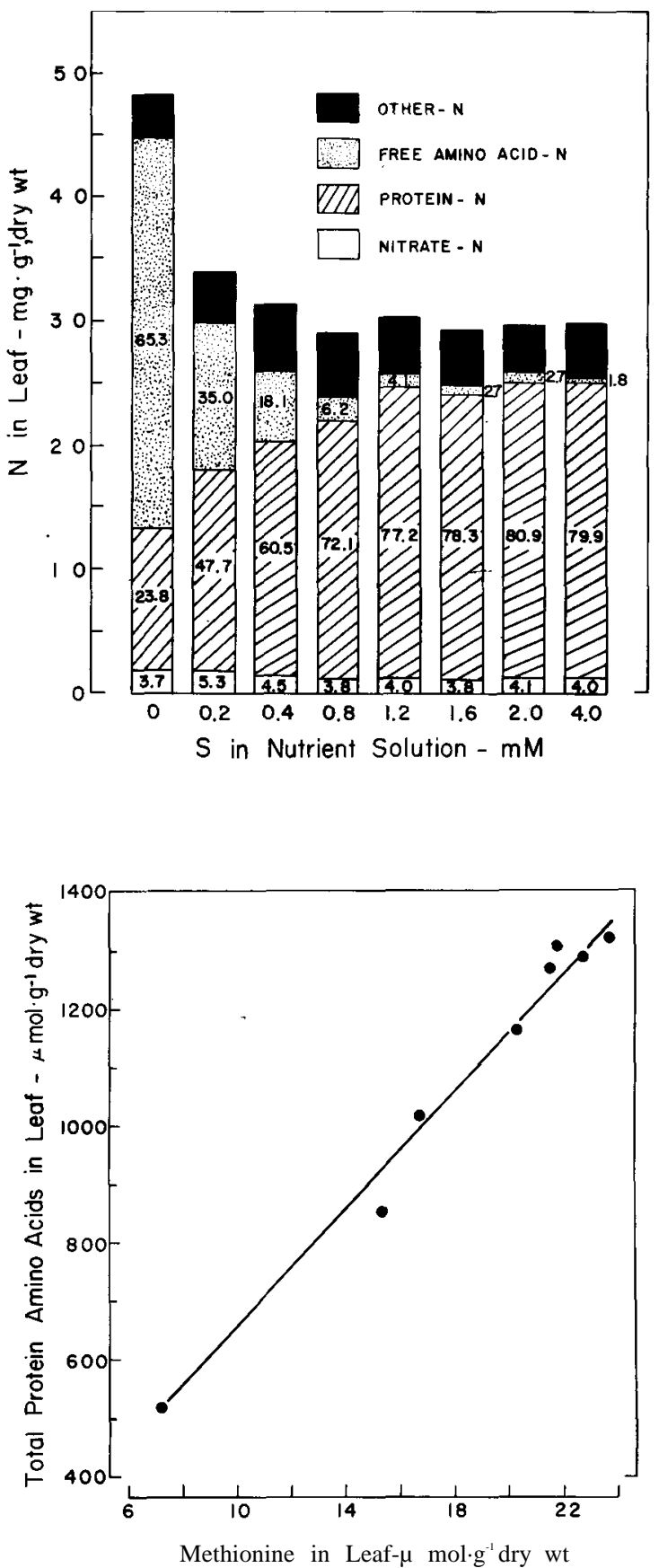

Fig. 10. Total protein amino acids vs. methionine in the pecan leaf. $\mathrm{Y}=200.2+47.95 \times, r^{2}=0.94, P \leq 0.01$.

free amino acid- $\mathrm{N}$ represented $65 \%$ of the total $\mathrm{N}$, thereby accounting for higher than normal total $\mathrm{N}$ associated with severe $\mathrm{S}$ deficiency in pecan. As $\mathrm{S}$ in the nutrient solution increased, the free amino acid-N dramatically decreased to $\approx 2 \%$ of the total $\mathrm{N}$. However, the reverse is true for protein amino acid-N, which constituted only $\approx 24 \%$ of the total $\mathrm{N}$ in the $\mathrm{O} \mathrm{mM} \mathrm{S}$ treatment. As $\mathrm{S}$ in the medium increased, protein amino acid$\mathrm{N}$ increased to $\approx 80 \%$ of the total $\mathrm{N}$ in the 2 - and $4-\mathrm{mM} \mathrm{S}$ treatments. Although the concentrations of $\mathrm{NO}_{3}-\mathrm{N}$ in the $\mathrm{O}-$ and $0.2-\mathrm{mM}$ treatments differed significantly from all other treatments, this $\mathrm{N}$ form was not highly correlated with $\mathrm{S}$ application, and the proportion of $\mathrm{NO}_{3}-\mathrm{N}$ to total $\mathrm{N}$ is essentially the same among the treatments. This relationship suggests that $\mathrm{NO}_{3}$ reduction is not significantly inhibited by $\mathrm{S}$ deficiency in pecan. 
This study clearly shows that free amino acid and protein accumulations are greatly altered by $\mathrm{S}$ deficiency in pecan, as in many other plant species (Bolton, 1976; Dietz, 1989; Eppendorfer, 1968; Klapheck et al.,1982; Macnicol,1983; Rendig et al., 1976; Stewart and Porter, 1969). The tremendously expanded free amino acid pool, mainly arginine, is the most conspicuous effect of $\mathrm{S}$ deficiency on $\mathrm{N}$ metabolism in pecan. Because the amino acid composition of the proteins did not change appreciably among treatments (Fig. 7), the accumulation of free amino acids under $\mathrm{S}$ deficiency may have been from that produced by de novo synthesis (Bergmann, 1981; Klapheck et al., 1982); Free arginine accumulation under $\mathrm{S}$ deficiency has also been reported in other plants (Bergmann, 1981; DeBorer and Duke, 1982; Dietz, 1989; Klapheck et al 1982; Macnicol, 1983), and S deficiency may stimulate its synthesis (Klapheck et al., 1982). In our study, the $\mathrm{N}$ sources were $\mathrm{NH}_{4}^{+}$and $\mathrm{NO}_{3}$. Arginine accumulation was apparently not due to $\mathrm{NH}_{4}^{+}$ as such, because free arginine also accumulated when $\mathrm{NO}{ }_{3}$ was the sole $\mathrm{N}$ source (Dietz, 1989).

Although asparagine and glutamine may be major $\mathrm{N}$ forms in transport of $\mathrm{N}$ in herbaceous plants, arginine appears to be the most important $\mathrm{N}$ storage form in pecan, as in other fruit trees (Bidwell and Durzan, 1975). This situation is suggested because plants receiving the highest $\mathrm{S}$ treatment, which had the lowest free amino acid pool, still had arginine constituting the highest percentage $(\approx 28 \%)$ of the total free amino acids. Similarly, arginine is high in pecan kernel, a storage organ .(Elmore and Polles, 1980; Meredith, 1974). Arginine is especially adapted to $\mathrm{N}$ storage because the proportion of $\mathrm{N}$ to $\mathrm{C}, 4: 6$, is higher than in other amino acids.

The lack of a correlation between the S-containing cystine and protein in pecan leaf and the linear relationship between protein and the S-containing methionine (Fig. 10) suggest that the reason for the reduced protein level under $\mathrm{S}$ deficiency may be the limited pool of free methionine for protein synthesis. However, Macnicol (1983) reported that in developing pea (Pisum sativum L.) seed, although free cystine level was greatly reduced under $\mathrm{S}$ deficiency, the relative levels of aminoacyl pool of cystine or methionine were not affected. A further study is needed to determine if the immediate cause for the lower protein level is due to the unavailable methionine or a lower total aminoacyl pool (Macnicol, 1983) or mRNA (Chandler et al., 1984) for protein synthesis.

\section{Literature Cited}

Adams, C.A. and R.W. Sheard. 1966. Alterations in the nitrogen metabolism of Medicago sativa and Dactylis glomerata as influenced by potassium and sulfur nutrition. Can. J. Plant Sci. 46:671-680.

Arnon, D.I. 1949. Copper enzymes in isolated chloroplasts. Polyphenoloxidase in Beta vulgaris. Plant Physiol. 24:1-5.

Bergmann, L. 1981. Aspects of S- and N-metabolism in tissue cultures, p. 341-351. In: H. Bothe and H. Trebst (eds.). Biology of inorganic nitrogen and sulfur. Springer-Verlag, New York.

Bidwell, R.G.S. and D.J. Durzan. 1975. Some recent aspects of nitrogen metabolism, p. 152-225. In: P.J. Davies (cd.). Historical and current aspects of plant physiology; A symposium honoring F.C. Steward, New York College .Agr. Life Sci., Ithaca, N.Y.

Bolton, J., T.Z. Nowakowski, and W. Lazams. 1976. Sulfur-nitrogen interaction effects on the yield and composition of the protein-N, nonprotein- $\mathrm{N}$ and soluble carbohydrates in perennial ryegrass. J. Sci. Food Agr. 27:553-560.

Cataldo, D. A., M. Haroon, L. E. Schrader, and V.L. Youngs. 1975. Rapid calorimetric determination of nitrate in plant tissue by nitration of salieylic acid. Commun. Soil Sci. \& Plant Anal. 6:71-80.

Chandler, P. M., D. Spencer, P.J. Randall, and T.J.V. Higgins. 1984. Influence of sulfur nutrition on developmental patterns of some major pea seed proteins and their mRNAs. Plant Physiol. 75:651-657.

DeBoer, D.L. and S.H. Duke. 1982. Effects of sulfur nutrition on nitrogen and carbon metabolism in lucerne (Medicago sativa L.). Physiol. Plant. 54:343-350.

Dietz, K.-J. 1989. Leaf and chloroplast development in relation to nutrient availability. J. Plant Physiol. 134:544-550.

Dijkshoorn, W. and A.L. van Wijk. 1967. The sulfur requirements of plants as evidenced by the sulphur-nitrogen ratio in the organic matter. A review of published data. Plant \& Soil 26:129-157.

Elmore, C.D. and S.G. Polles. 1980. Nitrogen fertilization effects on amino acid composition of pecan (Carya illinoensis) nutmeats. J. Agr. Food Chem. 28:902-904.

Eppendorfer, W. 1968. The effect of nitrogen and sulfur on changes in nitrogen fractions of barley plants at various early stages of growth and on yield and amino acid composition of grain. Plant \& Soil 29:424-437.

Ezekiel, M. and K.A. Fox. 1959. Methods of correlation and regression analysis. Wiley, New York.

Friedrich, J.W. and L.E. Schrader. 1978. Sulfur deprivation and nitrogen metabolism in maize seedings. Plant Physiol. 61 :9000903.

Giovanelli, J. 1987. Sulfur amino acids of pIant: An overview, 143:419426. In: W.B. Jakoby and O.W. Griffith (eds.). Sulfur and sulfur amino acids. Methods in enzymology. Academic, New York.

Helwig, J.T. and K.A. Council. 1979. SAS user's guide. SAS Institute, Inc., Raleigh, N.C.

Hoagland, D.C. and A.L Arnon. 1950. The water culture method for growing plants without soil. California Agr. Expt. Sta. Circ. 347.

Issac, R.A. and W.C. Johnson. 1976. Determination of total nitrogen in plant tissue. J. Assn. Offic. Anal. Chem. 59:98-100.

Jones, J. B., Jr. 1977. Elemental analysis of soil extracts and plant tissue ash by plasma emission spectroscopy. Commun. Soil Sci. Plant Anal. 8:349-365.

Jones, J.B., Jr., and R.A. Isaac. 1972. Determination of sulfur in plant material using a Leco sulfur analyzer. J. Agr. Food Chem. 20:12921294.

Klapcheck, S., W. Grosse, and L. Bergmann. 1982. Effect of sulfur deficiency on protein synthesis and amino acid accumulation in cell suspension cultures of Nicotiana tabacum. Z. Pflanzenphysiol. 108:235245.

Macnicol, P.K. 1983. Differential effect of sulfur deficiency on the composition of the aminoaeyl-tRNA and free amino acid pools of the developing pea seed. Fed. Eur. Biochem. Sot. Let. 156(1):55-57.

Meredith, F.I. 1974. Amino acid composition and quality in selected varieties of pecans Carya illinoensis. Fla. State Hort. Soc. 87:362-365.

Rendig, V. V., C. Oputa, and E.A. McComb. 1976. Effects of sulfur deficiency on nonprotein nitrogen, soluble sugars and N/S ratios in young corn (Zea mays L.) plants. Plant \& Soil 44:423-437.

Smith, G. S., I.S. Cornforth, and H.V. Henderson. 1985. Critical leaf concentrations for deficiencies of nitrogen, potassium, phosphorus, sulphur, and magnesium in perennial ryegrass. New Phytol. 101:393409.

Sparks, D. 1978. Nutrient concentrations of pecan leaves associated with deficiency symptoms and normal growth. HortScience 13:256-257.

Sparks, D. 1988. Growth and nutritional status in pecan in response to phosphorus. J. Amer. Sot. Hort. Sci. 113:850-859.

Stewart, B.A. and L.K. Porter. 1969. Nitrogen-sulfur relationship in wheat (Triticum aestivum L.), corn (Zea mays), and beans (Phaseolus vulgaris). Agron. J. 61:267-271.

Tabatabai, M.A. 1980. Profiling Soils, atmosphere, plants, depletion rate, Solutions 24:44, 46, 48, 50-51.

Tisdale, S. L., W.L. Nelson, and J.D. Beaten. 1985. Soil fertility and fertilizers. 4th ed. Macmillan, New York.

Ware, G. O., K. Ohki, and L.C. Moon. 1982. The Mitscherlich plant growth model for determining critical nutrient deficiency levels. Agron. J. 74:8891.

WiIkinson, W. S., C. Barbee, and F.E. Knox. 1968. Nutrient content of dehydrated coastal bermuda grass and pearl millet. J. Agr. Food Chem. 16:665-668. 